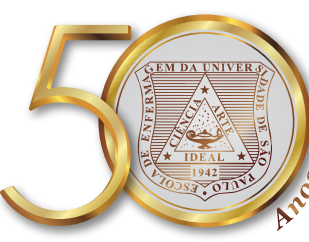

\title{
Adverse reactions to whole blood donation, basic human needs and nursing diagnoses: a reflection
}

\author{
Reações adversas à doação de sangue total, necessidades humanas básicas e diagnósticos de \\ enfermagem: uma reflexão \\ Reacciones adversas a la donación de sangre total, necesidades humanas básicas y diagnósticos \\ de enfermería: una reflexión
}

Gabriela Feitosa Esplendori ${ }^{1}$

How to cite this article:

Esplendori GF. Adverse reactions to whole blood donation, basic human needs and nursing diagnoses: a reflection. Rev Esc Enferm USP. 2017;51:e03284 DOI: http://dx.doi.org/10.1590/S1980-220X2017005003284

${ }^{1}$ Fundação Pró-Sangue Hemocentro de São Paulo, São Paulo, SP, Brazil.

\begin{abstract}
A theoretical-Reflective study with the objective to reflect on human needs regarding the imbalance of whole blood donors considering adverse reactions to the donation, and the existing nursing diagnoses that best meet the imbalance needs. The following needs were pointed out according to the signs and symptoms of adverse reactions and based on the Theory of Basic Human Needs: skin and tissue integrity, emotional security, pain perception, body mechanics, oxygenation, physical integrity, physical comfort, elimination, neurological, electrolytic and vascular regulation. By observing NANDA International's Definitions and Classifications, adaptations to the existing nursing diagnoses and suggestions for new headings have been proposed. We conclude that some of the needs are interrelated, such as vascular regulation, oxygenation and physical integrity. Thus, more contextualized nursing diagnoses related to the needs of whole blood donors are needed, given the specific nature of the situation generating imbalances such as: ineffective systemic vascular regulation characterized by self-reported dizziness, cutaneous pallor and arterial hypotension related to vasovagal reaction.
\end{abstract}

DESCRIPTORS

Blood Donors; Nursing Diagnosis; Nursing Theory.

Corresponding author:

Gabriela Feitosa Esplendori

Fundação Pró-Sangue

Hemocentro de São Paulo

Av. Dr. Enéas Carvalho de Aguiar, 155

$1^{\circ}$ andar, Setor Triagem Clínica

CEP 05403-000 - São Paulo, SP, Brazil Received: 02/07/2017

gabi_fei@yahoo.com.br

Approved: 08/29/2017 


\section{INTRODUCTION}

The occurrence of adverse reactions in whole blood donors lead these individuals experiencing a human need to an imbalance, considering there are signs and symptoms being perceived and/or reported; and if there are human needs in imbalance, such adverse reactions should be a matter of study and reflection by nurses who assist donors in hemotherapy services, since basic human needs can be considered as the "concrete body" of nursing ${ }^{(1)}$.

Blood donation consists of a safe procedure ${ }^{(2)}$ predominantly with no complications ${ }^{(3)}$. However, according to the Conceptual and Operational Hemovigilance Framework of the National Sanitary Surveillance Agency (ANVISA - Agência Nacional de Vigilância Sanitária) ${ }^{(4)}$, a donor may occasionally develop adverse reactions.

Adverse reaction can be understood as a donor's unintended response associated to collecting/donating whole blood, blood components or hematopoietic progenitor cells ${ }^{(4)}$. In this article, the adverse reactions resulting from donating a whole blood unit will be considered, a donation which allows us to draw a pint of blood with all the blood components, and which are further processed to obtain one or more components such as erythrocytes, plasma and platelets ${ }^{(5)}$.

The volume of whole blood to be drawn should be a maximum of $8 \mathrm{ml} / \mathrm{kg}$ of body weight for women and $9 \mathrm{ml} /$ $\mathrm{kg}$ of body weight for men, respectively. The volume allowed for whole blood donation is $450 \mathrm{ml}+-45 \mathrm{ml}$, to which a maximum of $30 \mathrm{ml}$ can be added for laboratory tests ${ }^{(5)}$. Usually a 16-gauge needle is used for the collection, which is inserted into a selected firm large-caliber vein, preferably in the cubital fossa region ${ }^{(6)}$.

Two considerations about the cubital region should be pointed out, considering the context of adverse reactions related to blood donation. The first of these consists of the fact that superficial veins of the cubital fossa such as the basilic vein, the cephalic vein, and the forearm intermediate vein, among others, have proximity to other structures; for example, the brachial artery, the cutaneous nerve of forearm, the median nerve and the biceps brachii muscle tendon ${ }^{(7)}$. The second is related to the fact that venous formations may present anatomical variations between individuals ${ }^{(8)}$.

Thus, in view of the process for obtaining a unit of whole blood and the anatomical aspects of the needle insertion site, adverse reactions can be classified as local or systemic.

The former presents localized symptoms resulting from needle insertion such as bruising, arterial puncture, irritation or nerve damage, tendon injury, post-donation bleeding, thrombophlebitis, and allergies. Among systemic reactions, the most common is vasovagal reaction, although hypovolemia and fatigue may also occur ${ }^{(4)}$.

Regarding their severity, mild reactions are those in which a localized symptom does not prevent the donor from carrying out usual activities; or systemic reactions, in which the recovery time is less than 30 minutes with subjective symptoms (dizziness, nausea and pallor). Moderate reactions consist of localized symptoms that prevent the donor from engaging in habitual activities or that persist for more than 2 weeks; or systemic reactions with objective symptoms such as loss of consciousness or hypotension requiring volume replacement ${ }^{(4)}$.

The occurrence of tetany is also classified as a moderate reaction ${ }^{(4)}$, being characterized by involuntary muscle contractions/spasms of the extremities ${ }^{(9,10)}$. Severe reactions are those that require hospitalization or intervention in order to avoid permanent damage, or when symptoms persist for more than 1 year $^{(4)}$; however, the need for hospitalization is rare, being mainly due to vasovagal reactions, but may also occur due to chest pain and arm injuries ${ }^{(11)}$.

The incidence of adverse reactions in whole blood donors up to 3 weeks after donation may reach one-third of donations ${ }^{(11)}$. A study of 1,034 donors describes hypotension, bruising, weakness and dizziness as the most common reactions ${ }^{(12)}$.

Specifically regarding the vasovagal reaction, some variables seem to be related to its occurrence such as female gender $^{(12-14)}$, first-time donors ${ }^{(13)}$, age ${ }^{(13,15)}$, body mass index ${ }^{(13)}$, weighing less than $55 \mathrm{~kg}^{(16)}$ and estimated blood volume ${ }^{(15-17)}$.

\section{BASIC HUMAN NEEDS AND IMPLICATIONS FOR CLINICAL REASONING IN NURSING TOWARD ADVERSE REACTIONS TO (WHOLE BLOOD) DONATION}

Adverse reactions to whole blood donation have objective and subjective signs and symptoms ${ }^{(4)}$. Recognizing them directs identifying needs in imbalance (or vulnerability), since "When needs manifest themselves, they do so by signs and symptoms"(1).

Also, basic human needs "are universal, therefore, common to all human beings; what varies from one individual to another is its manifestation and the way of satisfying or serving it" and "needs are not manifested in states of dynamic equilibrium, however they are latent and arise to a greater or lesser extent depend-

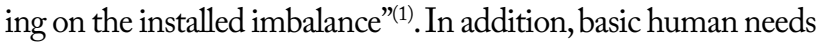
in imbalance may be interrelated in certain specific situations. This interrelationship of needs is known as nursing syndromes, which can be understood as "a set of basic human needs altered, interrelated, configuring a characteristic condition, and present in certain situations of human imbalance"(18).

Many are human needs that may be latent or unbalanced in individuals, among them: body mechanics, health education, cutaneous (skin and mucous) integrity, emotional safety, vascular regulation, nutrition, hydration, elimination, hormonal regulation, oxygenation, body care, sleep and rest, gregariousness/sociability, pain perception, communication, visual perception, auditory perception, immune regulation, self-realization, sexuality, physical integrity, self-image, exercise and physical activity, recreation, and life philosophy ${ }^{(19)}$. There are also needs regarding locomotion, auditory, olfactory and tactile perceptions, need for freedom, of orientation in time and space, self-esteem, attention, and of neurological, thermal and electrolytic regulation ${ }^{(1)}$.

Thus, adverse reactions resulting from whole blood donors indicate human needs in imbalance (or vulnerability) on which nurses must act. In fact, according to the Ministry of Health, donors who present an adverse reaction to the donation should remain in the hemotherapy service as long as necessary for their complete recovery ${ }^{(5)}$. 
Therefore, providing assistance to donors with adverse reactions is the responsibility of the nursing and medical team, professionals working in the clinical screening and collection.

Therefore, the objective of this article is to reflect on whole blood donors' human needs in imbalance according to mildly and moderately severe localized and systemic adverse reactions, and to draw a parallel with existing nursing diagnoses in the Nanda International's Definitions and Classifications of 2015-2017 that best fit the context of the listed reactions. The purpose of this objective is to contribute to clinical nursing reasoning in the context of hemotherapy, and to encourage reflection on more contextualized nursing diagnoses related to blood donation, of which in turn can be better developed for future proposals for NANDA International (NANDA-I).

Two steps were taken in order to list or name the basic human needs in imbalance (or vulnerability) from whole blood donors with mild and moderate local and systemic adverse reactions. The first consisted of observing the characteristic signs and symptoms of adverse reactions; the second consisted in naming the human needs that best corresponded to the signs and symptoms, according to the human needs described by Horta ${ }^{(1,19)}$.

In order to subsequently identify the nursing diagnoses that best fit the context of adverse reactions in whole blood donors, the nursing diagnoses existing in the NANDA International Definitions and Classifications (NANDA-I) were analyzed by reflections ${ }^{(20)}$.

\section{LOCAL ADVERSE REACTIONS AND HUMAN NEEDS IN IMBALANCE}

For reflection in this article regarding local reactions, "hematoma" and "arterial puncture" were chosen among the reactions essentially characterized by blood extravasation ${ }^{(4)}$, and "nerve irritation or injury" and "tendon injury" among those essentially characterized by pain ${ }^{(4)}$. Considering these four chosen reactions, the existence of a common symptom can be perceived: pain. Skin rupture is also common to the four local reactions due to the procedure inherent to the donation: venipuncture. Figure 1 shows other specific signs and symptoms of each local reaction. Considering that signs and symptoms manifest human needs ${ }^{(1)}$, Figure 1 also presents the human needs corresponding to the signs and symptoms.

As a result of the pain, it can be observed that the mechanics (i.e. the movements) of the affected limb become limited, either by conscious action of the donor in an attempt to protect them from increased pain perception caused by the movement, or according to guidance from health professionals who assisted them, giving them a recommendation to not perform movements that cause weight lifting on the affected limb or even efforts that may favor enlarging the hematoma or interfere with the healing process of the affected vessel, especially when it comes to an arterial puncture.

Thus, regarding local adverse reactions, it can be noticed that hematoma, arterial puncture, nerve irritation/injury or tendon injury lead to an imbalance in three basic human needs: skin integrity (due to the attempt to acquire venous

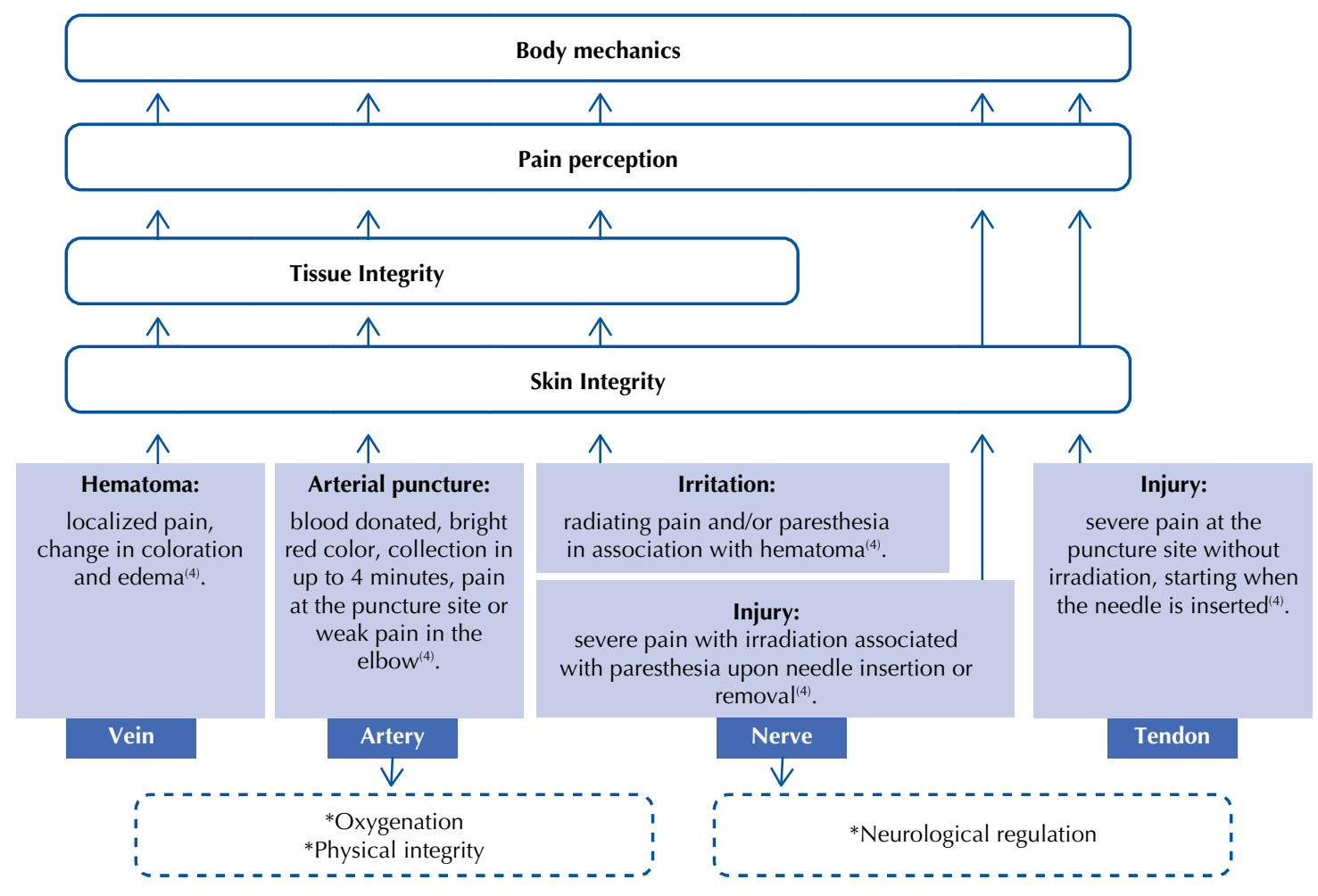

Legend: $\square=$ adverse reaction, $\square$ = human need in imbalance, $\left\llcorner_{---}^{-}=\right.$= human need in vulnerability .

Source: Adapted from the Conceptual and Operational Hemovigilance Framework by ANVISA ${ }^{(4)}$.

Figure 1 - Local adverse reactions from whole blood donors and the corresponding human needs. 
access for the donation to take place), pain perception (since the pain symptom is present in all four reactions), and body mechanics (since the pain generates limitation of movements in the affected arm). Given the relationship of these three human needs to the occurrence of local reactions and based on the concept of nursing syndromes, one could (in a reflective manner) dare to state that the set of needs composed by cutaneous integrity, physical and mechanical comfort composes a nursing syndrome that could be named Local Donor Syndrome, a nursing syndrome that is characteristic of the human being who before the action of donating blood is faced with local reactions related to the venous or arterial vessel, nerve or tendon of one of the upper limbs.

Considering "arterial puncture," it should be noted that other needs may come into imbalance. An arterial puncture may lead to an imbalance vulnerability of physical integrity due to the possibility of bleeding related to puncturing a pulsatile vessel, with possible risk of involving tissue oxygenation of distal regions to the upper limb's puncture area for the same reason of arterial vessel injury. In extremely rare cases, arterial puncture requires surgical intervention due to resulting pseudoaneurysms and arteriovenous fistulas ${ }^{(9)}$.

In the case of nerve damage, there is a need for neurological regulation of the affected limb. In the face of the trauma caused by the needle at the time of puncture or its removal, the nerve is vulnerable since there is risk of altered sensitivity and movement of the affected limb; eventually, although in very few cases, even when the donor receives all appropriate care in the hemotherapy service and follows all the guidelines of the health team for home care, morbidity and long-term disability could happen, with constant pain in the arm, or paraesthesia of the fingers when moving it, pain radiating to the forearm and shoulder, or reduced limb strength, among others ${ }^{(3)}$.

\section{ADVERSE SYSTEMIC REACTIONS AND HUMAN NEEDS IN IMBALANCE}

Regarding systemic reactions, the most common systemic reaction was considered: vasovagal reaction. Such a reaction is secondary to autonomic nervous system activation, and the volume and speed of blood drawn as well as psychological factors may contribute to its occurrence ${ }^{(4)}$. In response to blood loss, sympathetic excitation occurs first, and then parasympathetic activation related to mechanoreceptor stimulation located in the wall of the left ventricle and of vagal afferent pathways that react to the sympathetic response, leading to bradycardia and reduced blood pressure ${ }^{(21,22)}$.

Several signs and symptoms are characteristic of the vasovagal reaction $^{(4)}$, however they do not necessarily all occur simultaneously or in sequence. Figure 2 shows these signs and symptoms, and similarly to Figure 1 the corresponding human needs are listed.

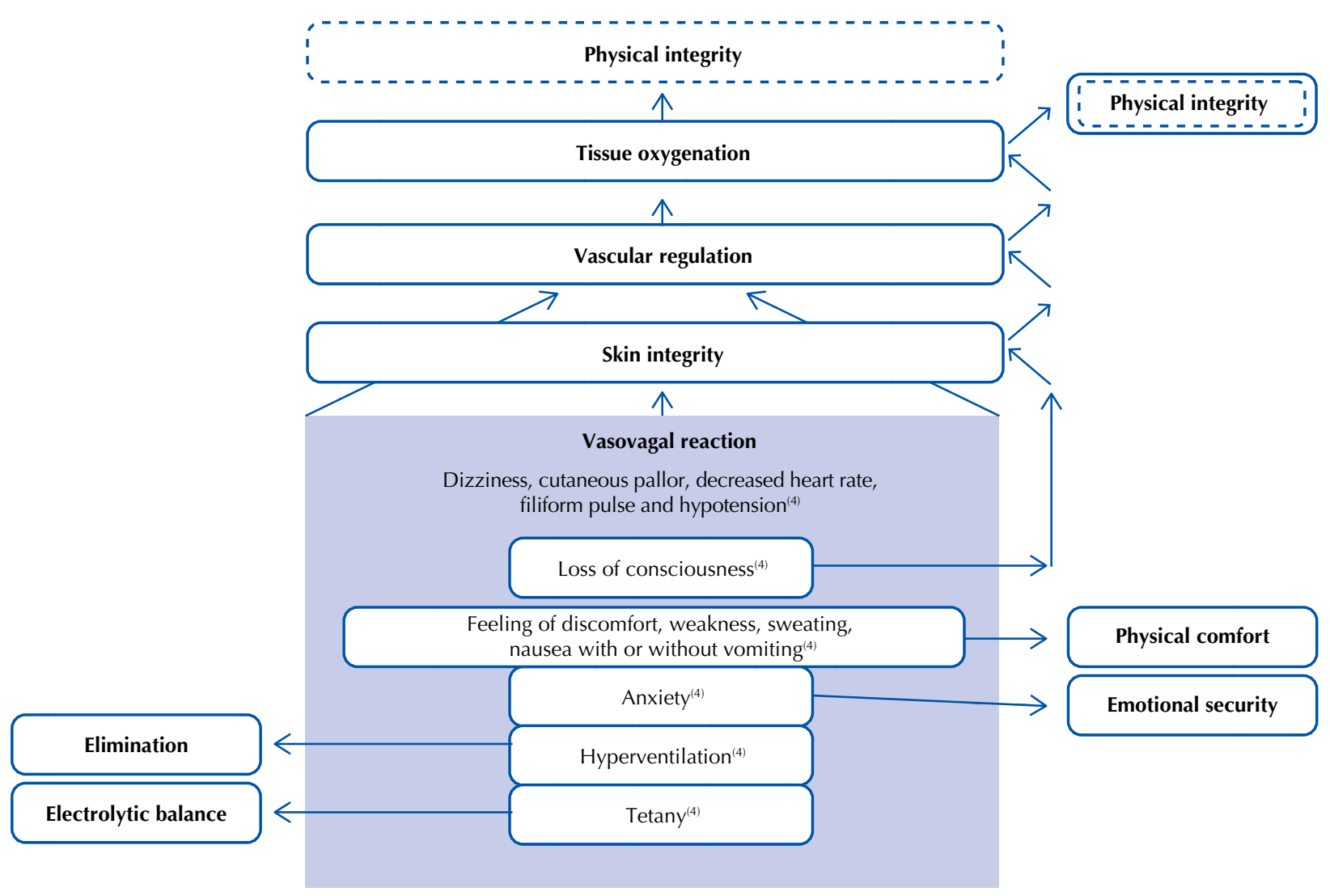

Legend: $\square=$ adverse reaction, $\square=$ human need in imbalance,,$r_{--}^{--}$?= human need in vulnerability .

Source: Adapted from the Conceptual and Operational Hemovigilance Framework by ANVISA ${ }^{(4)}$.

Figure 2 - Vasovagal reaction in whole blood donors and the corresponding human needs. 
It is emphasized that all the human needs related in Figure 2 were based on the needs listed by Horta ${ }^{(1,19)}$, with the exception of "physical comfort". This need was named for feelings of discomfort, weakness, sweating, and nausea with or without vomiting, based on an observation of the essential concepts which are important to nursing practice in describing "human responses"(20), since none of the needs described by Horta ${ }^{(1,19)}$ best representing these signs and symptoms of the vasovagal reaction were found.

Regarding the vasovagal reaction occurrence, some studies $^{(3,23)}$ describe a higher occurrence of vasovagal reaction without loss of consciousness. Thus, considering that the donor only feels dizziness, cutaneous pallor, filiform pulse, hypotension or decreased heart rate, we can observe the manifestation of two human needs in disequilibrium, and a third vulnerability.

The response of the parasympathetic autonomic nervous system implies the need for vascular regulation, as it causes reduced peripheral vascular resistance and heart rate, leading to a reduction in systemic blood pressure and cardiac output, and a consequent reduction in oxygen and nutrient supply (constituting a need for oxygenation and nutrition) to cerebral and peripheral tissues; this reduction is evidenced by dizziness and pallor. Thus, due to a reduction in self-perception and of the surrounding environment being experienced according to reports of dizziness and sometimes "darkened vision" $^{(24)}$, an imbalance in the need for cerebral oxygenation is also manifested. Therefore, the need for physical integrity is inevitably vulnerable, considering visual changes and dizziness due to reduced cerebral perfusion.

If the donor experiences syncope without falling from their own height on a level floor or without impact of any part of the body on rigid surfaces, as is the case when there is syncope on a chair at the post-donation site, the need for physical integrity remains in a state of vulnerability, despite the syncope. However, the vasovagal reaction may occasionally evolve into loss of consciousness with falls from their own height, potentiating the occurrence of morbidities such as bone fractures or cerebral contusion ${ }^{(3)}$. In these few cases, other needs such as orientation in time and space, body mechanics and locomotion may be affected.

The anxiety that may occur as a symptom of the vasovagal reaction can trigger hyperventilation ${ }^{(10)}$, which will put the need to eliminate carbon dioxide $\left(\mathrm{CO}_{2}\right)$ at vulnerability, since rapid and superficial respiratory movements favor $\mathrm{CO}_{2}$ release, thus reducing their plasma concentration which may also involve reducing ionized calcium plasma levels (need for electrolyte balance), causing neuromuscular hyperexcitability ${ }^{(25)}$. This situation is evidenced when there are reports of donor paresthesia in their lower, upper or perioral region. Such hyperventilation in some cases may trigger tetany ${ }^{(10)}$.

\section{ADVERSE REACTIONS AND EXISTING NURSING DIAGNOSES}

Chart 1 and 2 list the adverse reactions and their settings in the NANDA International Definitions and Classifications (NANDA-I) ${ }^{(20)}$, as well as the most adequate nursing diagnoses for the signs and symptoms, in view of the human needs mentioned in Figures 1 and 2.

In order to contextualize diagnoses regarding whole blood donation, the need to make suggestions regarding the defining characteristics (DC), related factors $(\mathrm{ReF})$ or risk factors $(\mathrm{RiF})$ have been identified. I point out that the suggestions of $\mathrm{DC}, \mathrm{ReF}$ and $\mathrm{RiF}$, or even the suggestion of some descriptors/modifiers ${ }^{(20)}$ to the existing diagnoses were made only as a proposition for new reflections in the sense of contextualizing the diagnoses related to whole blood donation.

Regarding nerve injury, a nursing diagnosis that could be better developed and subsequently proposed to the NANDA International (NANDA-I) would be: Risk of sensory neurological regulation and/or impaired motor of the upper limb related to unintentional nerve puncture in the cubital fossa for performing whole blood donation.

Chart 1 - Local adverse reactions and nursing diagnoses according to the NANDA-I (20), with suggestions for the context of whole blood donation.

\begin{tabular}{|c|c|}
\hline Adverse reaction & $\begin{array}{l}\text { Most appropriate existing nursing diagnosis } \\
\text { (Note: uppercase words represent the author's suggestions) }\end{array}$ \\
\hline \multirow{2}{*}{$\begin{array}{l}\text { - Hematoma } \\
\text { Arterial puncture } \\
\text { Nerve irritation } \\
\text { Q Nerve injury } \\
\text { - Tendon injury }\end{array}$} & 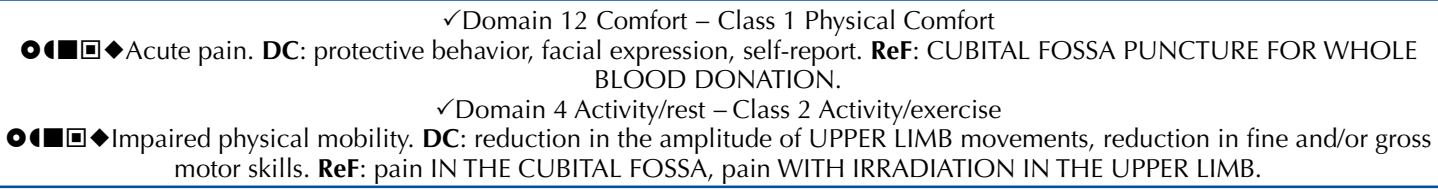 \\
\hline & $\begin{array}{l}\qquad \text { Domain } 11 \text { Safety/protection - Class } 2 \text { Physical injury } \\
\text {-1 Impaired tissue Integrity. DC: LOCAL EDEMA, ALTERATION OF SKIN COLORATION IN THE PUNCTURE REGION, PAIN IN THE } \\
\text { REGION OF THE ELBOW, RADIANTING PAIN. ReF: PUNCTURE IN THE CUBITAL FOSSA FOR WHOLE BLOOD DONATION. }\end{array}$ \\
\hline \multirow{3}{*}{ Arterial puncture } & $\checkmark$ Domain 4 Activity and rest - Class 4 Cardiovascular/pulmonary responses \\
\hline & $\begin{array}{c}\text { Risk of ineffective peripheral tissue perfusion. RiF: UNINTENTIONAL PUNCTURE OF THE ARTERY IN THE CUBITAL REGION, } \\
\text { PRESENCE OF SYNTHETIC MATERIAL IN THE ARTERY FOR SECONDS/MINUTES. }\end{array}$ \\
\hline & $\begin{array}{l}\qquad \text { Domain } 11 \text { Safety/protection - Class } 2 \text { Physical injury } \\
\text { Risk of bleeding. RiF: UNINTENTIONAL PUNCTURE OF THE ARTERY IN THE CUBITAL REGION FOR WHOLE BLOOD DONATION. }\end{array}$ \\
\hline Nerve injury & $\begin{array}{l}\checkmark \text { Domain } 5 \text { Perception/cognition - Class } 3 \text { Sensation/perception } \\
\text { No diagnosis so far. }\end{array}$ \\
\hline
\end{tabular}

Legend: The symbols $\mathbf{0 1} \square$ indicate the correspondence between local reaction and nursing diagnoses, $\mathbf{D C}=$ defining characteristic, $\mathbf{R e F}=$ related factor, $\mathbf{R i F}=$ risk factor. 
Chart 2 - Vasovagal reaction and nursing diagnoses according to the NANDA- ${ }^{(20)}$, with suggestions for the context of whole blood donation.

\begin{tabular}{|c|c|}
\hline Adverse reaction & $\begin{array}{l}\text { Most appropriate existing nursing diagnosis } \\
\text { (Note: uppercase words represent the author's suggestions) }\end{array}$ \\
\hline $\begin{array}{l}\text { Dizziness } \\
\text { Skin pallor } \\
\text { Decreased heart } \\
\text { rate } \\
\text { Filiform pulse } \\
\text { Arterial hypotension }\end{array}$ & $\begin{array}{l}\checkmark \text { Domain } 4 \text { Activity and rest }- \text { Class } 4 \text { Cardiovascular/pulmonary responses } \\
\text { 1. SITUATIONAL decreased cardiac output. DC: altered post-load: decreased systemic vascular resistance, decreased } \\
\text { peripheral pulse, cold and sticky skin, skin pallor, changes in blood pressure. ReF: VASOVAGAL REACTION RESULTING } \\
\text { FROM WHOLE BLOOD DONATION. } \\
\text { 2. INEFFECTIVE SITUATIONAL BRAIN TISSULAR INFUSION. DC: SELF-REPORTED DIZZINESS AND/OR VERTIGO, } \\
\text { IMPAIRED VISION. ReF: SITUATIONAL decreased cardiac output RESULTING FROM WHOLE BLOOD DONATION. } \\
\checkmark \text { Domain } 11 \text { Safety/protection - Class } 2 \text { Physical injury } \\
\text { Risk of trauma. RiF: IMPAIRED vision, SELF-REPORTED DIZZINESS AND/OR VERTIGO. }\end{array}$ \\
\hline $\begin{array}{l}\text { Feeling of } \\
\text { discomfort } \\
\text { Sweating } \\
\text { Nausea with } \\
\text { Or without vomiting }\end{array}$ & $\begin{array}{l}\checkmark \text { Domain } 12 \text { Comfort }- \text { Class } 1 \text { Physical Comfort } \\
\text { 1. Impaired Comfort. DC: report of feeling of discomfort, restlessness, inability to relax, hot sensation. ReF: VASOVAGAL } \\
\text { REACTION RESULTING FROM WHOLE BLOOD DONATION. }\end{array}$ \\
\hline Anxiety & $\begin{array}{l}\checkmark \text { Domain } 9 \text { Coping/stress tolerance - Class } 2 \text { Coping responses } \\
\text { Anxiety. DC: nervousness, restlessness, increased respiratory rate. ReF: VASOVAGAL REACTION RESULTING FROM } \\
\text { WHOLE BLOOD DONATION. }\end{array}$ \\
\hline Hyperventilation & $\begin{array}{l}\text { VDomain } 4 \text { Activity and rest - Class } 4 \text { Cardiovascular/pulmonary responses } \\
\text { Ineffective respiratory pattern. DC: abnormal respiratory pattern: depth and frequency. ReF: ANXIETY ARISING FROM } \\
\text { WHOLE BLOOD DONATION. }\end{array}$ \\
\hline Syncope & $\begin{array}{l}\checkmark \text { Domain } 4 \text { Activity and rest - Class } 4 \text { Cardiovascular/pulmonary responses } \\
\text { IMPAIRED SITUATIONAL TISSULAR BRAIN INFUSION. DC: Ioss of consciousness. ReF: SITUATIONAL decreased cardiac } \\
\text { output RESULTING FROM WHOLE BLOOD DONATION. } \\
\checkmark \text { Domain } 11 \text { Safety/protection - Class } 2 \text { Physical injury } \\
\text { Risk of trauma. RiF: LOSS OF CONSCIOUSNESS WITHOUT IMPACT OF THE BODY ON RIGID STRUCTURES/GROUND. }\end{array}$ \\
\hline
\end{tabular}

Legend: $\mathbf{D C}=$ defining characteristic, $\mathbf{R e F}=$ related factor, $\mathbf{R i F}=$ risk factor.

Regarding the vascular regulation affected by the parasympathetic paradoxical response in the vasovagal reaction (without loss of consciousness), a more contextualized diagnosis for whole blood donation could be: Ineffective systemic vascular regulation characterized by hypotension/cutaneous pallor/verbal report of dizziness/filiform pulse/decreased heart rate related to the vasovagal reaction resulting from whole blood donation.

Regarding the occurrence of tetany, a more contextualized diagnosis related to whole blood donation could be: Electrolyte imbalance related to ionized calcium in plasma characterized by contractions/involuntary muscle spasms of the extremities related to the vasovagal reaction in whole blood donors.

\section{FINAL CONSIDERATIONS}

Within the context of whole blood donation, nurses who assist donors with adverse reactions face individuals who have human needs in imbalance (or vulnerability) translated into signs and symptoms related to the integrity of their skin and tissues, emotional security, body mechanics, pain perception, vascular regulation, tissue oxygenation, neurological regulation, physical integrity, physical comfort, and electrolytic regulation. Based on the identification of these needs and the existing nursing diagnoses in the NANDA International Definitions and Classifications of 2015-2017, suggestions for new headings/titles and adaptations to existing ones were made in order to better contextualize nursing care in the scenario of adverse reactions to whole blood donation.

General and specific care to be provided by the nursing and medical staff assisting donors with adverse reactions is numerous. Discussing such care is beyond the scope of this theoretical reflection article; however, understanding how to perform such care is facilitated and scientifically better understood when acquiring clinical nursing reasoning based on human needs in imbalance or vulnerability.

\section{RESUMO}

Estudo teórico-Reflexivo, cujo objetivo foi refletir sobre as necessidades humanas em desequilíbrio de doadores de sangue total diante de reações adversas à doação e sobre os diagnósticos de enfermagem existentes que mais se adéquam às necessidades em desequilíbrio. De acordo com os sinais e sintomas das reações adversas, tomou-se por base a Teoria das Necessidades Humanas Básicas e foram elencadas as seguintes necessidades: integridade de pele e tecidos, segurança emocional, percepção dolorosa, mecânica corporal,oxigenação, integridade física, conforto físico, eliminação, regulações neurológica, eletrolítica e vascular. Ao observar as Definições e Classificações da $N A N D A$ International, realizaram-se propostas de adaptações aos diagnósticos de enfermagem já existentes e sugestões de novos enunciados. 
Conclui-se que algumas necessidades estão inter-relacionadas, como regulação vascular, oxigenação e integridade física. São necessários diagnósticos de enfermagem mais contextualizados às necessidades de doadores de sangue total, haja vista o caráter específico da situação geradora de desequilíbrios, como exemplo: regulação vascular sistêmica ineficaz caracterizada por autorrelato de tontura, palidez cutânea e hipotensão arterial relacionada à reação vasovagal.

\section{DESCRITORES}

Doadores de Sangue; Diagnóstico de Enfermagem; Teoria de Enfermagem.

\section{RESUMEN}

Estudio teórico-Reflexivo, cuyo objetivo fue reflejar acerca de las necesidades humanas en desequilibrio de donantes de sangre total frente a las reacciones adversas a la donación y acerca de los diagnósticos de enfermería existentes que más se adecuan a las necesidades en desequilibrio. De acuerdo con las señales y los síntomas de las reacciones adversas, se tomó como base la Teoría de las Necesidades Humanas Básicas y fueran enlistadas las siguientes necesidades: entereza de piel y tejidos, seguridad emocional, percepción dolorosa, mecánica corporal, oxigenación, integridad física, confort físico, eliminación, regulaciones neurológica, electrolítica y vascular. Al observar las Definiciones y Clasificaciones de la NANDA International, se realizaron propuestas de adaptaciones a los diagnósticos de enfermería ya existentes y sugerencias de nuevos enunciados. Se concluye que algunas necesidades están interrelacionadas, como regulación vascular, oxigenación e integridad física. Son necesarios diagnósticos de enfermería más contextualizados a las necesidades de donantes de sangre total, en virtud del carácter específico de la situación generadora de desequilibrios, como ejemplo: regulación vascular sistémica ineficaz caracterizada por autorrelato de tontura, palidez cutánea e hipotensión arterial relacionada con reacción vasovagal.

\section{DESCRIPTORES}

Donantes de Sangre; Diagnóstico de Enfermería; Teoría de Enfermería.

\section{REFERENCES}

1. Horta, WA. Human Basic Needs: a general outline. Enferm Nov Dimens. 1975;1(5):266-8.

2. Pan American Health Organization; World Health Organization. Eligibility for blood donation: recommendations for education and selection of prospective blood donors [Internet]. Washington: PAHO; 2009 [cited 2016 nov. 10]. Available from: http://www1.paho.org/hq/dmdocuments/2009/EligiBlood09EN.pdf?ua=1

3. Dogra A, Sidhu M, Dogra M, Raina TR. Study of adverse whole blood donor reactions in normal healthy blood donors: experience of tertiary Health Care Centre in Jammu Region. Indian J Hematol Blood Transfus. 2015;31(1):142-5. DOI : 10.1007/s12288-014-0396-y

4. Brasil. Ministério da Saúde; Agência Nacional de Vigilância Sanitária. Marco Conceitual e Operacional de Hemovigilância: guia para a hemovigilância no Brasil [Internet]. Brasília; 2015 [citado 2016 nov. 10]. Disponível em: http://portal.anvisa.gov.br/ documents/33868/404938/guia_ hemovigilancia15.pdf/495fd617-5156-447d-ad22-7211cdbab8a7

5. Brasil. Ministério da Saúde. Portaria n. 158, de 4 de fevereiro de 2016. Redefine o regulamento técnico de procedimentos hemoterápicos [Internet]. Brasília; 2016 [citado 2016 nov. 15]. Disponível em: http://bvsms.saude.gov.br/bvs/saudelegis/gm/2016/prt0158_04_02_2016.html

6. World Health Organization. Diretrizes da OMS para a tiragem de sangue: boas práticas em flebotomia [Internet]. Geneva: WHO; 2016 [citado 2016 dez. 05]. http://www.who.int/injection_safety/Phlebotomy-portuges_web.pdf

7. Hansen JT. Nether anatomia clínica. Rio de Janeiro: Elsevier; 2015.

8. Alves N. Formações venosas superficiais da fossa cubital: aspectos de interesse para a prática da enfermagem. Rev Bras Enferm. 2012;65(6): 1030-3. DOI: 10.1590/S0034-71672012000600021

9. Simon TL, McCullough, Synder EL, Solheim BG, Strauss RG, editors. Rossi's principles of transfusion medicine. 5th ed. Hoboken: Willey Blackwell; 2016.

10. Almeida RGS, Mazzo A, Mendes IAC, Trevisan MA, Godoy S. Caracterização do atendimento de uma Unidade de Hemoterapia. Rev Bras Enferm. 2011;64(6):1082-6. DOI 10.1590/S0034-71672011000600014

11. Brasil. Ministério da Saúde; Secretaria de Gestão do Trabalho e da Educação na Saúde, Departamento de Gestão do Trabalho na Saúde. Técnico em hemoterapia: livro texto [Internet]. Brasília: MS; 2013 [citado 2016 dez. 16]. Disponível em: http://www.hemocentro.unicamp. br/dbarquivos/tecnico_em_hemoterapia.pdf

12. Nchinda EC, Tagny CT, Mbanya D. Blood donor haemovigilance in Yaoundé, Cameroon. Transfus Med. 2012;22(4):257-61. DOI: $10.1111 / \mathrm{j} .1365-3148.2012 .01161 . x$

13. Narbey D, Fillet AM, Jbilou S, Tiberghien P, Djoudi R. Case-control study of immediate and delayed vasovagal reactions in blood donors. Vox Sang. 2016;111(3):257-65. DOl 10.1111/vox.12418

14. Ditto B, Gilchrist PT, Holly CD. Fear-related predictors of vasovagal symptoms during blood donation: it's in the blood. J Behav Med. 2012;35(4):393-9. DOI 10.1007/s10865-011-9366-0

15. Bravo M, Kamel H, Custer B, Tomasulo P. Factors associated with fainting - before, during and after whole blood donation. Vox Sang. 2011;101(4):303-12. DOI: 10.1111/j.1423-0410.2011.01494.x.

16. Joseph P, Sarkar RS, Neelesh J. A single-centre study of vasovagal reaction in blood donors: Influence of age, sex, donation status, weight, total blood volume and volume of blood collected. Asian J Transfus Sci. 2014;8(1):43-6. DOI: 10.4103/0973-6247.126690

17. Takanashi M, Odajima T, Aota S, Sudoh M, Yamaga Y, Ono Y, et al. Risk factor analysis of vasovagal reaction from blood donation. Transfus Apher Sci. 2012;47(3):319-25. DOI: 10.1016/j.transci.2012.04.002

18. Horta WA. Síndromes de enfermagem. Rev Enferm Novas Dimens.1978;4(1):17-8. 
19. Horta WA. Consulta de enfermagem. Rev Esc Enferm USP.1975;9(3):53-7.

20. NANDA International. Diagnósticos de enfermagem da NANDA: definições e classificações 2015-2017. Porto Alegre: Artmed; 2015.

21. Iwase S, Nishimura N, Mano T. Role of sympathetic nerve activity in the process of fainting. Front Physiol. 2014;5:343. DOI: $10.3389 /$ fphys.2014.00343

22. Sever P. Hypotension and ischaemic stroke associated with aliskiren in the ALTITUDE trial: Sensitisation of the Bezold-Jarisch Reflex? J Renin Angiotensin Aldosterone Syst. 2013; 14(1):1-2. DOI: 10.1177/1470320312468832

23. Goncalez TT, Sabino EC, Schlumpf KS, Wright DJ, Leao S, Sampaio D, et al. Vasovagal reactions in whole blood donors at 3 REDS-II blood centers in Brazil. Transfusion. 2012; 52(5):1070-7. DOI: 10.1111/j.1537-2995.2011.03432.x

24. Braz ACG, Almeida RGS, Martinez EZ. Translation into Portuguese and validation of the Blood Donation Reactions Inventory. Rev Bras Hematol Hemoter. 2014;36(2):139-46. DOI: 10.5581/1516-8484.20140031

25. Molina PE. Fisiologia endócrina. 4ª ed. São Paulo: AMGH; 2014. 